\title{
CONSUMER PERCEPTIONS AND BEHAVIOR ON DIAMONDS IN INDIA
}

\author{
Dr. Ravi Kumar Goriparthi and Dr. Bersisa Kacho
}

\begin{abstract}
This paper aims at understanding how consumers perceive Diamonds and how that affects their behavior. This paper uses data from an empirical quantitative research survey with a total of 150 respondents to study consumers' perceptions and behavior using factor and cluster analysis. The Main drivers of consumer behavior in Diamonds are design, price, and trust. Consumers require trust since it is difficult for them to understand and evaluate how the price is determined for a Diamonds. Overall consumers care what they buy, but it seems that they have insufficient information on their purchases and this is the main problem with consumerism. Based on this study consumers are willing to make extra efforts to get decently made Diamonds and the majority of consumers, are genuinely interested in Diamonds. Two main managerial implications are: First, Diamonds companies should now invest and study Diamonds ecommerce. Second, consumers expect that businesses will improve on their corporate social responsibility. This is a trend train that does not wait and fast adapters gain more market share.
\end{abstract}

Key words: Perceptions, Behavior, Design, Price, and Trust

\section{INTRODUCTION}

Diamonds since time immemorial in India has remained the owner's pride, they have remained exotic, unequalled and invaluable articles of personal glory and, with diamonds becoming symbol of status, fashion and taste, men and women today are steadily moving away from conventional styles of adornment and ornamentation and are gradually adopting modern patterns better suited to their busy life styles. Considering the fact that India is the largest consumer of gold and has excellent infrastructure for diamond cutting and it is the second largest foreign exchange earner in India. Consumer buying behavior in diamonds industry can be studied on the internal parameters such as design, price, and trust as consumers looks for the best deal on the things that they want to buy and are expecting companies to market products to show why their product should be bought and where that product can be found, and the consumer buying behavior is a complex process as a number of internal and external factors influence the buyer's decision making which is a process of buying starts in the mind of the consumer, which helps them to find out alternatives available in the market. A consumer who is highly involved with a product would be interested in knowing a lot about it before purchasing. Hence he reads brochures thoroughly, compares brands and models available at different outlets, as question, and look for recommendations, thus consumer buying behavior can be defined as heightened state of awareness that motivates consumer's to think about product information prior to purchase. Thus the study of consumer helps the diamonds companies to improve their marketing strategies by understanding issues related to design, price, and trust.

\section{RESEARCH PROBLEM}

The key approach of this paper is to explore how the consumer perceives diamonds and how this translates to his or her behavior and to make concrete managerial implications which in turn should benefit the company in increased sales and customer loyalty so the main topic of this paper is consumer behavior, and its interpretation precisely What are the consumer perceptions towards the diamond industry. To understand the question three questions, arise: what is typical consumer behavior, what are the typical consumer groups, how do these groups behave? Answering these questions bring a deep understanding on how the issues and the behavior are related. 


\section{OBJECTIVES OF THE STUDY}

The main objective of the study is to find out how do consumers perceive diamonds, and how do these perceptions affect their purchasing behavior. To synthesize the objective five sub-objectives are developed to improve subject clarity:

1. To find out the characteristics of customer behavior in diamonds

2. To find out How do consumers perceive issues related to diamonds

3. To find out what are the characteristics of the main consumer groups in diamonds

4. To find out what affects the purchasing decision of the customer in diamonds

5. To find out what are the key managerial implications on the bases of consumer behavior in diamonds

\section{HYPOTHESES OF THE STUDY}

H1. There are clear consumer groups, which can be grouped by their thinking and behavior.

H2. The level of education increases sensitivity towards issues in diamonds .

H3. From experience, activation, and expression of emotions, it is experience that is most important to diamonds shopping.

H4. Diamonds shopping is a common self-rewarding behavior.

H5. A comfortable atmosphere increases the probability to shop diamonds

H6. Consumer will prefer "decent" Diamonds to "normal" Diamonds.

H7. Consumer is ready to pay extra for decent Diamonds.

H8. There is not enough "decent" Diamonds to choose from.

H9. On average, customers feel that they are not getting enough product information.

H10. Company transparency increases customer loyalty.

\section{METHODOLOGY OF THE STUDY}

This study draws its information from a quantitative web survey was carried out to test the main hypotheses, the population of this study are Indians aged 30 and over, is considered by using systematic sampling. Most significant part of the questionnaire was the Likert-scale attitude claims representing questions. Three advanced multivariate techniques are used to analyze the data. First, factor analysis is used to group the different attitude claims to factors behaving similarly. Second, the respondents are grouped using cluster analysis. Finally, these groups are analyzed according to their behavior using some basic statistical analysis tools namely $t$-test, and analysis of variance.

\section{LIMITATIONS OF THE STUDY}

This study was limited mainly in the time-frame for in which the survey was planned and conducted, nevertheless, as the subject is vast, the questionnaire served its purpose well and revealed many key characteristics of Diamonds buying consumers. Then, a good notion is the fact that attitude research does not necessarily prove behavior, often, they are two different matters what people say they will do and how they will actually behave. Despite that this may have an effect, arguably the results overall point to the right direction, and can be trusted.

\section{FACTOR ANALYSIS}

The factor analysis was carried out first by determining which variables were to fit in to the analysis and subsequently the variables with lower than \pm 0.4 factor loading were left out. Together these variables formed ten individual factors, which can be seen from Table 1.

\section{Table 1 Factors representing customer perceptions on Diamonds shopping behavior}

\begin{tabular}{|l|l|l|l|}
\hline Factor & Metric & $\begin{array}{l}\text { Factor } \\
\text { Loadings }\end{array}$ & $\begin{array}{l}\mathrm{h}^{2} \\
\text { bach's } \\
\text { Alpha }\end{array}$ \\
\hline $\begin{array}{l}\text { Highly responsible and active } \\
\text { Diamonds shopping. }\end{array}$ & I am prepared to pay extra for decently made Diamonds & 0.691 & 0.495 \\
\cline { 2 - 4 } & $\begin{array}{l}\text { I am ready and prepared to make extra efforts when I purchase } \\
\text { Diamonds, which I trust are decent }\end{array}$ & 0.721 & 0.911 \\
\cline { 2 - 4 } & I prefer to buy Diamonds of decent origins & 0.701 & 0.612 \\
\cline { 2 - 4 } & Diamonds should be manufactured decently & 0.723 & 0.390 \\
\cline { 2 - 4 } & Decent manufacturing of Diamonds is important to me & 0.732 & 0.740 \\
\cline { 2 - 4 } & I am ready to participate actively to promote decent Diamonds & 0.596 & 0.521 \\
\cline { 2 - 4 } & $\begin{array}{l}\text { The environmental manufacturing process of Diamonds is important } \\
\text { to me }\end{array}$ & 0.598 & 0.603 \\
\hline
\end{tabular}




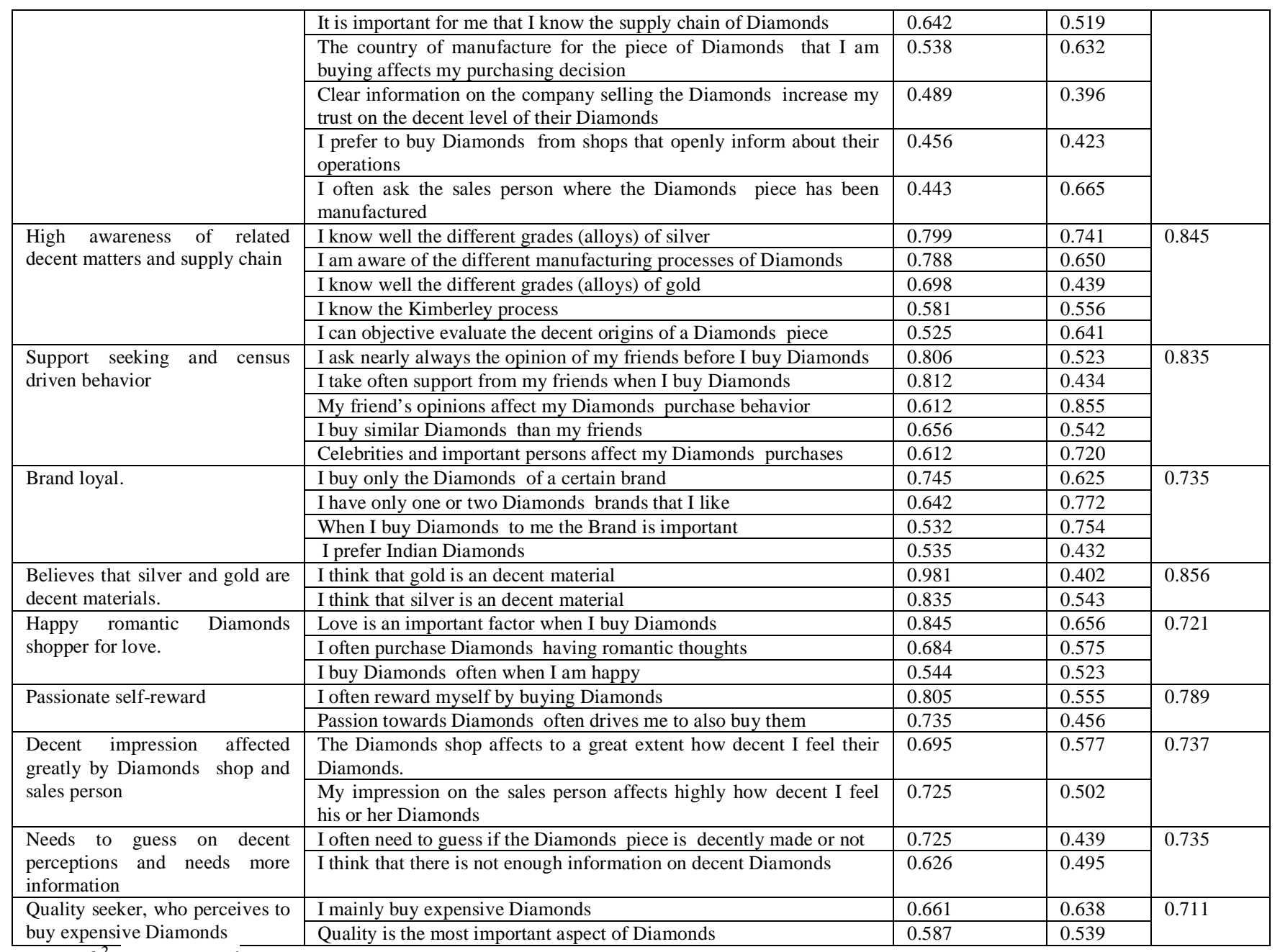

Note: $h^{2}$-Eta squared

The respondents in this study showed all in all ten individual dimensions how they perceive the issues in Diamonds as follows: Highly responsible and active Diamonds shopping (0.911) there exerts efforts, high awareness of related decent matters and supply chain (0.845) there exists awareness, support seeking and census driven behavior (0.835), brand loyal (0.735) there exists loyalty, believes that silver and gold are decent materials (0.856), Happy romantic Diamonds shopper for love (0.721) usually to romantic purposes, passionate self-reward (0.789) Decent impression affected greatly by Diamonds shop and sales person (0.737) sales person affects the Diamonds shopper Needs to guess on decent perceptions and needs more information (0.735) insufficient information on Diamonds and therefore cannot judge if the Diamonds piece is of decent origins or not, Quality seeker, who perceives to buy expensive Diamonds (0.711) seeks quality and is willing to pay considerably, based on one's perception.

\section{CLUSTER ANALYSIS}

\section{Table 2 Cluster centers for the group of consumers}

\begin{tabular}{|l|l|l|l|l|l|}
\hline Factor & $\begin{array}{l}\text { Posi } \\
\text { tivists }\end{array}$ & $\begin{array}{l}\text { Casual } \\
\text { shoppers }\end{array}$ & $\begin{array}{l}\text { Brand } \\
\text { loyalists }\end{array}$ & $\begin{array}{l}\text { Critical } \\
\text { negativists }\end{array}$ & $\begin{array}{l}\text { Good-doers } \\
\text { sionists }\end{array}$ \\
\hline Highly responsible and active Diamonds shopping. & -.49659 & -.42914 & -.31096 & -.36303 & 1.01677 \\
\hline $\begin{array}{l}\text { High awareness of related decent matters and supply } \\
\text { chain }\end{array}$ & .59799 & -.73257 & -1.23313 & .44028 & .42639 \\
\hline Support seeking and census driven behavior & .02731 & -.60702 & .53501 & 15374 & .05403 \\
\hline Brand loyal. & .18899 & -.50683 & .55095 & 05191 & .24348 \\
\hline Believes that silver and gold are decent materials. & .83348 & -.14272 &. .17187 & -1.10163 &. .04969 \\
\hline
\end{tabular}




\begin{tabular}{|l|l|l|l|l|l|l|}
\hline Happy romantic Diamonds shopper for love. & .35574 & -.19372 & .19100 & -.21330 & 04935 \\
\hline Passionate self-reward & .27129. & .07055 & -.47514 & .38857 & -.24545 \\
\hline $\begin{array}{l}\text { Decent impression affected greatly by Diamonds shop } \\
\text { and sales person }\end{array}$ & -.14494 & -.10734 & .36520 & -.46936 & -.01999 \\
\hline $\begin{array}{l}\text { Needs to guess on decent perceptions and needs more } \\
\text { information }\end{array}$ & -.22827 & .48716 & -.72794 & -.33699 & -.72052 \\
\hline $\begin{array}{l}\text { Quality seeker, who perceives to buy expensive } \\
\text { Diamonds }\end{array}$ & .22346 & -.20133 & -.07412 & -.06034 & 77635 \\
\hline
\end{tabular}

For this study cluster analysis was considered which is set between two to seven clusters.

There is a fairly good spread among the different clusters with two and seven clusters, since they give perhaps too little or too spread information of the different customers groups. The cluster centers explain the general relation to the underlying factor. Therefore, to have a better understanding of the individual clusters, grouping the factors depending their relation to the clusters is applicable table 3 explains how the different clusters relate to the ten factors. For clarity of the analysis, in the table factors with a high relation $(> \pm 0.4)$ to its cluster are marked bold, where as those with weak relation $(< \pm 0.2)$ are colored. Those with lower than \pm 0.1 were left out from the analysis. Also, to increase the explaining power of the table three factors of highest relation are highlighted with numbers one to three.

\section{Table 3: Clusters related to factors}

\begin{tabular}{|c|c|c|c|c|}
\hline & \multicolumn{2}{|l|}{ Positive Relation (> 0.4) } & \multicolumn{2}{|l|}{ Negative Relation $(<0.1)$. } \\
\hline & Strong & Weak & Strong & Weak \\
\hline \multirow[t]{5}{*}{ Positivists } & $\begin{array}{l}\text { Believes that silver and gold } \\
\text { are decent materials }\end{array}$ & \multirow[t]{5}{*}{ Brand loyal } & $\begin{array}{l}\text { Highly responsible and active } \\
\text { Diamonds shopping }\end{array}$ & \multirow{5}{*}{$\begin{array}{l}\text { Decent impression } \\
\text { affected greatly by Diamonds } \\
\text { shop and sales person }\end{array}$} \\
\hline & $\begin{array}{l}\text { High awareness of } \\
\begin{array}{l}\text { decent matters and } \\
\text { chain }\end{array}\end{array}$ & & \multirow[t]{4}{*}{$\begin{array}{llrr}\text { Needs to guess on decent } \\
\text { perceptions } & \text { and needs more } \\
\text { information } & & & \end{array}$} & \\
\hline & $\begin{array}{l}\text { Happy romantic Diamonds } \\
\text { shopper for love }\end{array}$ & & & \\
\hline & Passionate self reward & & & \\
\hline & $\begin{array}{l}\text { Quality seeker, who perceives } \\
\text { to buy expensive Diamonds }\end{array}$ & & & \\
\hline \multirow[t]{5}{*}{$\begin{array}{l}\text { Casual } \\
\text { shoppers }\end{array}$} & \multirow{5}{*}{$\begin{array}{l}\text { Needs to guess on decent } \\
\text { perceptions and needs more } \\
\text { information }\end{array}$} & & $\begin{array}{l}\text { High awareness of related decent } \\
\text { matters and supply chain }\end{array}$ & $\begin{array}{l}\text { Happy romantic } \\
\text { Diamonds hopper for love }\end{array}$ \\
\hline & & & $\begin{array}{l}\text { Support seeking and census driven } \\
\text { behavior }\end{array}$ & $\begin{array}{l}\text { Believes that silver and gold } \\
\text { are decent materials }\end{array}$ \\
\hline & & & Brand loyal & \multirow{3}{*}{$\begin{array}{l}\text { Decent impression affected } \\
\text { greatly by Diamonds shop } \\
\text { and sales person }\end{array}$} \\
\hline & & & $\begin{array}{l}\text { Highly responsible and active } \\
\text { Diamonds shopping }\end{array}$ & \\
\hline & & & $\begin{array}{l}\text { Quality seeker, who perceives to } \\
\text { buy expensive Diamonds }\end{array}$ & \\
\hline \multirow[t]{4}{*}{ Brand loyalists } & Brand loyal & $\begin{array}{l}\text { Happy romantic } \\
\text { Diamonds shopper } \\
\text { for love }\end{array}$ & $\begin{array}{l}\text { High awareness of related decent } \\
\text { matters and supply chain }\end{array}$ & \\
\hline & $\begin{array}{l}\text { Support seeking and census } \\
\text { driven behavior }\end{array}$ & \multirow[t]{3}{*}{$\begin{array}{l}\text { Believes that silver } \\
\text { and gold are decent } \\
\text { materials }\end{array}$} & $\begin{array}{lllr}\text { Needs to } & \text { guess } & \text { on } & \text { decent } \\
\text { perceptions } & \text { and needs } & \text { more } \\
\text { information } & & & \end{array}$ & \\
\hline & \multirow{2}{*}{$\begin{array}{l}\text { Decent impression affected } \\
\text { greatly by Diamonds shop } \\
\text { and sales person }\end{array}$} & & Passionate self-reward & \\
\hline & & & $\begin{array}{l}\text { Highly responsible and active } \\
\text { Diamonds shopping }\end{array}$ & \\
\hline \multirow[t]{4}{*}{$\begin{array}{l}\text { Critical } \\
\text { negativists }\end{array}$} & \multirow{4}{*}{$\begin{array}{l}\text { High awareness of } \\
\text { related decent matters and } \\
\text { supply chain }\end{array}$} & \multirow{4}{*}{$\begin{array}{l}\text { Support seeking } \\
\text { and } \\
\text { census driven } \\
\text { behavior }\end{array}$} & $\begin{array}{l}\text { Believes that silver and gold are } \\
\text { decent materials }\end{array}$ & \\
\hline & & & $\begin{array}{l}\text { Decent impression affected greatly } \\
\text { by Diamonds shop and sales } \\
\text { person }\end{array}$ & \\
\hline & & & $\begin{array}{l}\text { Highly responsible and active } \\
\text { Diamonds shopping }\end{array}$ & \\
\hline & & & $\begin{array}{l}\text { Needs to guess on decent } \\
\text { perceptions and needs more } \\
\text { information }\end{array}$ & \\
\hline
\end{tabular}




\begin{tabular}{|c|c|c|c|}
\hline & $\begin{array}{l}\text { Passionate self } \\
\text { reward }\end{array}$ & & $\begin{array}{l}\text { Happy romantic Diamonds } \\
\text { shopper for love }\end{array}$ \\
\hline \multirow[t]{4}{*}{ Good-doers } & $\begin{array}{l}\text { Highly responsible and active } \\
\text { Diamonds shopping }\end{array}$ & \multirow{4}{*}{$\begin{array}{l}\text { Believes that silver } \\
\text { and gold are ecent } \\
\text { materials }\end{array}$} & \\
\hline & $\begin{array}{l}\text { Needs to guess on decent } \\
\text { perceptions and needs more } \\
\text { information }\end{array}$ & & \\
\hline & $\begin{array}{l}\text { Support seeking and } \\
\text { census driven behavior3 }\end{array}$ & & \\
\hline & Brand loyal & & \\
\hline \multirow[t]{5}{*}{ Impressionists } & \multirow{2}{*}{$\begin{array}{l}\text { Decent impression affected } \\
\text { greatly by Diamonds shop } \\
\text { and sales person }\end{array}$} & & Passionate self-reward \\
\hline & & & $\begin{array}{lllr}\text { Needs to } & \text { guess } & \text { on } & \text { decent } \\
\text { perceptions } & \text { and needs } & \text { more } \\
\text { information } & & & \end{array}$ \\
\hline & $\begin{array}{l}\text { High awareness of } \text { related } \\
\text { decent matters and supply } \\
\text { chain }\end{array}$ & & Brand loyal \\
\hline & \multirow[t]{2}{*}{$\begin{array}{l}\text { Highly responsible } \\
\text { and active Diamonds } \\
\text { shopping }\end{array}$} & & $\begin{array}{l}\text { Happy romantic Diamonds } \\
\text { shopper for love }\end{array}$ \\
\hline & & & $\begin{array}{l}\text { Believes that silver and gold are } \\
\text { decent materials }\end{array}$ \\
\hline
\end{tabular}

Table 3 interprets on the basis of functions in the clusters. The factors having the highest relation to the clusters either in a strong positive loading, or negative, act as the main indicators, and reveal the characteristics of the specific group. Therefore, the clusters can be named as follows:

Positivists like to think they know much, but actually the social, decent, environmental matters do not really count when they are buying Diamonds.

Casual shoppers have low awareness, they are independent shoppers, they are not loyal to brands, they rely on their perceptions, and are not too much concerned of social, decent, environmental matters do not really count when they are buying. However, they would like to receive much more information of the social, decent, environmental facts in Diamonds.

Brand loyalists go with the flow, rely to others, and have low awareness, but understand that there are important social, decent, environmental matters behind their choices.

Critical negativists perceive Diamonds as indecent, are critical to new information, and like to think they are aware of the social, decent, environmental matters in Diamonds.

Good-doers are extremely active and responsible Diamonds buyers. However, they still need to rely much on their perceptions, and thus would like to receive much more information of the social, decent, environmental facts in Diamonds.

Impressionists are the softer version of good-doers. They are affected greatly by the Diamonds shop image and the sales person, perhaps by asking always a lot of questions. They like to think they are aware of the social, decent, environmental matters in Diamonds, and understand that they are important issues.

\section{CLUSTER COMPARISONS.}

In order to study and define the consumer groups in depth, a number of cross tabulations through clusters were considered which shows a deeper understanding of the underlying characteristics of the consumer groups. From the table 4 one can notice that there are statistically significant differences among several claims. These claims were selected from the list of variables that were left with factor analysis.

Table 4: Analysis of variance on cluster groups on selected variables

\begin{tabular}{|c|c|c|c|c|c|c|}
\hline Attitude claims & $\mathbf{B} / \mathbf{W}$ & SS $x$ & MS & df & $\mathbf{F}$ & Sig. \\
\hline \multirow{2}{*}{$\begin{array}{l}\text { It is important to me that there has not been used any child labor } \\
\text { in the Diamonds manufacturing process }\end{array}$} & B & 22.009 & 4.4 & 5 & \multirow[t]{2}{*}{6.2} & \multirow[t]{2}{*}{.000} \\
\hline & $\mathrm{W}$ & 285.740 & 0.7 & 401 & & \\
\hline \multirow[t]{2}{*}{ I think that there are not enough decent Diamonds in the market } & $\mathrm{B}$ & 19.154 & 3.8 & 5 & \multirow[t]{2}{*}{7.4} & \multirow[t]{2}{*}{.000} \\
\hline & $\mathrm{W}$ & 206.473 & 0.5 & 401 & & \\
\hline \multirow[t]{2}{*}{ I buy Diamonds with time and consideration } & $\mathrm{B}$ & 20.214 & 4.0 & 5 & \multirow[t]{2}{*}{4.0} & \multirow[t]{2}{*}{.002} \\
\hline & $\mathrm{W}$ & 407.594 & 1.0 & 401 & & \\
\hline \multirow{2}{*}{$\begin{array}{l}\text { It is important to me that the person producing the Diamonds } \\
\text { piece gets a sufficient pay for the job }\end{array}$} & $\mathrm{B}$ & 28.589 & 5.7 & 5 & \multirow[t]{2}{*}{11.4} & \multirow[t]{2}{*}{.000} \\
\hline & $\mathrm{W}$ & 200.591 & 0.5 & 401 & & \\
\hline I know or know what is decent consuming & $\mathrm{B}$ & 45.175 & 9.0 & 5 & 10.7 & .000 \\
\hline
\end{tabular}




\begin{tabular}{|c|c|c|c|c|c|c|}
\hline & $\mathrm{W}$ & 338.309 & 0.8 & 401 & & \\
\hline \multirow{2}{*}{$\begin{array}{l}\text { I often visit many Diamonds shops in order to get } \\
\text { what I want }\end{array}$} & B & 12.530 & 2.5 & 5 & \multirow[t]{2}{*}{1.8} & \multirow[t]{2}{*}{.115} \\
\hline & $\mathrm{W}$ & 564.025 & 1.4 & 401 & & \\
\hline \multirow[t]{2}{*}{ I buy often Diamonds at discounts } & B & 5.490 & 1.1 & 5 & \multirow[t]{2}{*}{0.7} & \multirow[t]{2}{*}{.608} \\
\hline & $\mathrm{W}$ & 610.579 & 1.5 & 401 & & \\
\hline \multirow{2}{*}{$\begin{array}{l}\text { I buy Diamonds mainly because of their aesthetic } \\
\text { beauty }\end{array}$} & $\mathrm{B}$ & 22.661 & 4.5 & 5 & \multirow[t]{2}{*}{3.3} & \multirow[t]{2}{*}{.189} \\
\hline & $\mathrm{W}$ & 546.499 & 1.4 & 401 & & \\
\hline \multirow{2}{*}{$\begin{array}{l}\text { When I want I can buy Diamonds that is } \\
\text { decently made }\end{array}$} & B & 23.226 & 4.6 & 5 & \multirow[t]{2}{*}{6.8} & \multirow[t]{2}{*}{.000} \\
\hline & $\mathrm{W}$ & 272.204 & 0.7 & 401 & & \\
\hline \multirow{2}{*}{$\begin{array}{l}\text { I mainly evaluate how decent a piece of Diamonds is based on my } \\
\text { gut feelings }\end{array}$} & $\mathrm{B}$ & 5.485 & 1.1 & 5 & \multirow[t]{2}{*}{1.5} & \multirow[t]{2}{*}{.006} \\
\hline & $\mathrm{W}$ & 293.178 & 0.7 & 401 & & \\
\hline \multirow{2}{*}{$\begin{array}{l}\text { I buy Diamonds most likely when there is a pleasant atmosphere in } \\
\text { the store }\end{array}$} & B & 9.746 & 1.9 & 5 & \multirow[t]{2}{*}{1.6} & \multirow[t]{2}{*}{.160} \\
\hline & $\mathrm{W}$ & 489.488 & 1.2 & 401 & & \\
\hline \multirow[t]{2}{*}{ It is important that I am able to trust the sales person } & B & 21.853 & 4.4 & 5 & \multirow[t]{2}{*}{7.5} & \multirow[t]{2}{*}{.000} \\
\hline & $\mathrm{W}$ & 232.585 & 0.6 & 401 & & \\
\hline \multirow[t]{2}{*}{ I know my consumer rights } & B & 99.794 & 20.0 & 5 & \multirow[t]{2}{*}{18.2} & \multirow[t]{2}{*}{.000} \\
\hline & $\mathrm{W}$ & 438.653 & 1.1 & 401 & & \\
\hline
\end{tabular}

Note: Claims showing differences among the consumer groups are shown bold.

\section{SSx - Sum of Squares}

Yet, not all of these claims show statistical significance. If one requires a high F-value with equally high statistical significance $(\mathrm{p}=0.000)$, claims showing differences among the consumer groups are shown bold satisfy this. To bring the selection of these variables even further down, let us look at those four with highest F-value, which is (Table 5) interesting to note the other sentences that did not contain much variance across the cluster groups. Therefore, the value of these sentences lay, actually, in the measurement of the whole Diamonds buying population.

Table 5: Comparison of means across consumers groups on selected variables

\begin{tabular}{|c|c|c|c|c|c|}
\hline & eta2 & 0.125 & 0.118 & 0.086 & 0.185 \\
\hline \multirow[t]{3}{*}{ Positivists } & Mean & 1.50 & 2.42 & 1.58 & 3.25 \\
\hline & $\mathrm{N}$ & 84 & 84 & 84 & 84 \\
\hline & S D & .668 & .921 & .732 & 1.129 \\
\hline \multirow{3}{*}{$\begin{array}{l}\text { Casual } \\
\text { shoppers }\end{array}$} & Mean & 1.67 & 2.33 & 1.48 & 2.12 \\
\hline & $\mathrm{N}$ & 85 & 85 & 85 & 85 \\
\hline & S D & .643 & .662 & .590 & .837 \\
\hline \multirow{3}{*}{$\begin{array}{l}\text { Brand } \\
\text { loyalists }\end{array}$} & Mean & 1.49 & 2.27 & 1.51 & 2.78 \\
\hline & $\mathrm{N}$ & 37 & 37 & 37 & 37 \\
\hline & S D & 507 & .871 & .768 & 1.158 \\
\hline \multirow{3}{*}{$\begin{array}{l}\text { Critical } \\
\text { negativists }\end{array}$} & Mean & 1.51 & 2.51 & 1.25 & 2.86 \\
\hline & $\mathrm{N}$ & 63 & 63 & 63 & 63 \\
\hline & S D & .592 & .914 & .474 & 1.090 \\
\hline \multirow[t]{3}{*}{ Good-doers } & Mean & 2.18 & 3.07 & 1.91 & 3.30 \\
\hline & $\mathrm{N}$ & 91 & 91 & 91 & 91 \\
\hline & S D & $\begin{array}{l}.864 \\
\end{array}$ & 1.020 & .950 & 1.049 \\
\hline \multirow{3}{*}{ Impressionists } & Mean & 1.83 & 3.11 & 1.89 & 3.62 \\
\hline & $\mathrm{N}$ & 47 & 47 & 47 & 47 \\
\hline & S D & .816 & 1.127 & .961 & 1.074 \\
\hline
\end{tabular}

Note: $\quad$ Highest agreement to the statement is indicated by grey highlight and lowest by bold

Scale used is the Likert scale from 1 to 5 (high to low agreement).

It seems that the Brand loyalists are, in fact, the most concerned in relative terms of the decent matters behind Diamonds. Also, in the case of critical negativists, it is good to note the significance they also place on trusting the seller. Clearly, the brand loyalists spend the most, whereas especially the positivists tend to buy less. Analysis on price category spending shows that men have a tendency to buy more expensive pieces than women. This is an interesting notion, since too often men are not targeted in the Diamonds advertisement. Thus, a clear managerial implication would be to target men more in expensive price category's keeping in mind that they eventually buy the product. Overall, the cross tabulations bring more information of the cluster groups. In fact, in light of this understanding there can be now made new observations for the clusters.

Positivists: They are young, well educated, with lowest income. They are interested of buying from Internet.

Casual shoppers are more likely men than women, since they have a relative higher portion of men among the group. They are older, and know their consumer rights, therefore shopping to them is more practical task and they like to do their shopping in a convenient way to them, most importantly, they are good spenders. 
Brand loyalists are older, well educated, with the highest income. They like to trust their brands and arguably spend on expensive luxury brands, thus making highest relative spending.

Critical negativists are also older, but with lowest education. They are medium spenders, and are the smallest group. They are the only group strongly believing that silver and gold are not decent materials.

Good-doers are young, who have only a medium spending on Diamonds. They like to do the 'right' thing and want more information. Therefore, a key competitive advantage in the fight of these customers, in the coming years, is to have as much as possible transparent information present explaining the origins and sources of the raw materials and parts used in the Diamonds they are buying.

Impressionists are also young, but they are well educated. However, they do not know their consumer rights well. Overall, they are interested of buying from Internet, and they are medium spenders, like to ask a lot of questions, and are easily affected by the seller's knowledge.

\section{DISCUSSION}

From the hypothesis made from H1 to H10 it would be most straightforward to confirm are $\mathbf{H 1}$ and $\mathbf{H 4}$. On the basis of the survey results one can clearly confirm these two; both have a strong agreement and only a marginal disagreement. In other word, a comfortable shopping atmosphere does impact positively the shop sales, and that there is a clear trend that the customers do not get enough product information. Second, the hypothesis $\mathbf{H 3}$ was discovered false as there is a clear sign that self-rewarding and Diamonds do not go well together, in fact, it is a clear managerial implication, since self-rewarding should not thus be overemphasized. Third, the hypothesis $\mathbf{H} \mathbf{2}$ was rather difficult to measure $\mathrm{n}$ terms of how emotions are activated and expressed. However, in the light of the survey results, it can be confirmed that emotions do play a big role in Diamonds shopping Diamonds causes instant emotional reactions, Diamonds is bought commonly when being happy, and with love. Fourth, when coming to hypothesis H5, it can be understood that the individual's education level does not seem to have a linkage to the sensitivity towards decent, social, and environmental issues in Diamonds. Thus, this hypothesis is invalid. In fact, on the bases on the research results, it can be said that the sensitivity is independent of the person's education level.

Fifth, from the factor and cluster analysis hypothesis $\mathbf{H 6}$ can be confirmed positive but the decision on the number of groups has naturally some effects, (a) The majority of irresponsible consumers seems to be older men, (b) the responsible consumers are younger and a new generations. Sixth, the hypothesis $\mathbf{H 7}$ assumed that the consumers prefer "decent" Diamonds to "normal" Diamonds, and the research findings show that this assumption confirms the consumer preference towards decent Diamonds. Seventh, hypothesis H8 tests whether or not the consumers are ready to pay more or not of Diamonds of decent origins, the statistical analysis that grouped six consumer groups showed that Positivists and Casual shoppers, are not too much concerned of the decent matter, so H8 cannot be confirmed but it can be said that a significant amount of consumers would be willing to pay more of Diamonds of decent origins. Eight hypothesis $\mathbf{H 9}$ can be confirmed as the responses is so great that this hypothesis creates a clear implication to increase customer loyalty and preference. Finally, the question whether there is or there is not enough "decent" Diamonds to choose from, showed an interesting observation of the Diamonds industry from customer's point of view, $\mathbf{H 1 0}$ cannot be confirmed as there is not enough information available on decent Diamonds, and thus the customer does not know how to choose decent Diamonds .

\section{CONCLUSIONS}

This study investigates how perceptions affect consumers' purchasing behavior and the majority of the hypotheses are in general proven to be correct, although some are discovered false, but the main results reflect now a more holistic view on how the social, issues relate to the consumer's purchasing behavior. There are three main factors that affect consumer behavior are design, price, and trust. It is good to note while brands are important function to create trust, company transparency and honest communication drives trust in to the consumers' heart. Despite that they might not be willing to make extra effort, nor pay more, they would prefer products of which their sound origins they can be sure of. Also, many noted that currently there is not enough information present about the Diamonds and their origins. To gain a competitive advantage, or merely improve customer loyalty, there are three things to consider. First, a complete check on company supply chain should be made to reflect. Second, company transparency should be improved which means openly discussing the origins of the raw materials and subassemblies. Third, branding and communication in general, are useful tools and the impact of it should not be underestimated, which should then make the choice easy for the consumer to make. All that is needed is plain and honest information on how the Diamonds market operates, where the materials and finished products come from, and how they are manufactured by giving the consumer more information and by educating him and herself, the 
investment should bring significant returns. This study provides many good lessons on Diamonds industry and insights and suggestions how to improve and develop a better Diamonds business. In conclusion diamond industry is seen in a positive light, so they should value their creative personnel highly and show it to them as well. Although, the materials used might vary but to stay connected human behavior and interaction is a must.

\section{REFERENCES}

[1]. Aiello, G. Donvito, R. Godey, B. Pederzoli, D. et al. 2009. An international perspective on luxury brand and country-of-origin effect. Journal of Brand Management. London. Mar-May 2009. Vol. 16, Iss. 5-6; p.323. 15p.

[2]. Antonides, G. Raaij, W.F. 1998. Consumer Behavior - A European Perspective. John Wiley and Sons Ltd. Chichester, England. 619p.

[3]. Armstrong, J.S. Overton, T.S. 1977. Estimating nonresponse bias in mail surveys. Journal of Marketing Research. XIV. August. p.396-402.

[4]. Arnold, M.J. Reynolds, K.E. Ponder, N. Lueg, J.E. 2005. Customer delight in a retail context: investigating delightful and terrible shopping experiences. Journal of Business Research, Volume 58, Issue 8, August 2005, p.1132-1145.

[5]. Arnould, E. Price, L. Zinkhan, G. 2004. Consumers. McGraw-Hill Companies Inc. New York.

[6]. Cavender, R.S. 2009. Luxury goods: Still strong sellers. China Business Review. Vol 36:2. p.36-39

[7]. Chandrashekaran, R., \& Grewal, D. (2006). Anchoring effects of advertised reference price and sale price: The moderating role of saving presentation format., 69 (10111) 106311071.

[8]. Chan Kim, W and Mauborgne, R. 2005. Blue Ocean Strategy: How to Create Uncontested Market Space and Make Competition Irrelevant. Harward business school publishing group.

[9]. Chevalier, M. Mazzalovo, G. 2008. Luxury Brand Management - A world of proviledge. John Wiley \& Sons (Asia) Pte. Ltd. 421p.

[10]. Cudeck, R. 2000. Chapter 10: Exploratory Factor Analysis. Handbook of Applied Multivariate Statistics and Mathematical Modelling.

[11]. De Mooij, M. 2004. Consumer behavior and culture. Consequences for global Marketing and Advertising. Sage Publications Inc. London. 345 p.

[12]. Flemming, H. Christensen, S.R. 2007. Emotions, Advertising and Consumer Choice. Copenhagen Business School Press. 462p.

[13]. Jayawardhena, C. Wright, L. T. Masterson, R. 2003. An investigation of online consumer purchasing. Qualitative Market Research Bradford: Vol. 6, Iss. 1; p. 58, 8p.

[14]. Jean-Ruel, E., 2008. The effect of ethical attributes on brand personality and consumer brand relationships. Concordia University (Canada). 50.

[15]. Jones, J.L. Middleton, K.L. 2007. Ethical Decision-Making by Consumers: The Roles of Product Harm and Consumer Vulnerability. Journal of Business Ethics. 70. p.247-264

[16]. Kau, A.K. Tang, Y.E. Ghose, S. 2003. Typology of online shoppers. The Journal of Consumer Marketing. Santa Barbara: Vol. 20, Iss. 2/3; p.139, 18p.

[17]. Mazumdar, T., Raj, S. P., \& Sinha, I. (2005). Reference price research: Review and propositions. 69 (4), 841102. M

[18]. Rajendran, K. N., \& Tellis, G. J. (1994). Contextual and temporal components of reference price.58 (1), 22134.

[19]. Sinha, I., \& Smith, M. F. (2000). Consumer perceptions of promotional framing of price. 17 (3), 257175.

[20]. Sambandam, R. Cluster analysis gets complicated. Marketing Research. Spring 2003.p.16-21.

[21]. Sanguanpiyapana, T. Jasper, C. 2009. Consumer insights into luxury goods: Why they shop where they do in a jewelry shopping setting. Journal of Retailing and Consumer Services. Volume 17, Issue 2, March 2010. p.52-160.

[22]. Vassilikopoulou, A. I. Siomkos, G. J. Mylonakis, J. 2005 Clustering consumers according to their attitudes on corporate social responsibility. International Journal of Business Governance and Ethics. Olney: Vol. 1, Iss. 4. p.317

[23]. Wardlow, D.L. 1996. Gays, Lesbians, and Consumer Behavior. Theory, Practice, and Research issues in Marketing. Harrington Park Press. New York. 261p.

[24]. Zaltman, G. 2003. How Consumers think. Essential insights into the mind of the market. Harward Business School Press. Boston, Massachusetts.

\section{WEB SITES:}

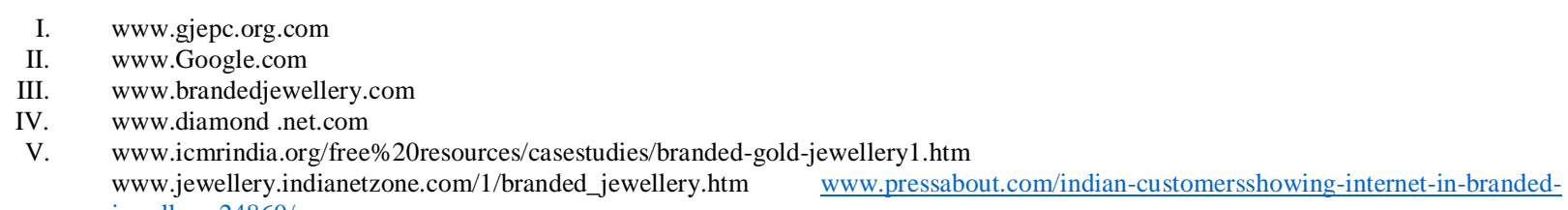

